\section{A New Series of Analgesics}

A sERIES of potent analgesics, as active as morphine in the rat, has been discovered in the 3-tertiaryamino-1 : 1-(2'-thienyl)-but-I-enes (I). The analgesic toxicity ratios are not greatly different from that of amidone (II ; $R=\mathrm{Me}$ ).<smiles></smiles>

$$
\text { I }
$$

$\left.\mathrm{CPh}_{2}{ }^{\prime} \mathrm{COEt}\right) \cdot \mathrm{CH}_{2} \cdot \mathrm{CHMe} \cdot \mathrm{N} R_{2}$ It

It is interesting that, as with other analgesics, the analgesia is accompanied by temperature and respiratory depression and by sedation in many laboratory animals, that an excitatory phase is manifest, particularly in the cat, and that high doses cause spasticity of the muscles and 'Straub tail' in rodents. The analgesic dose in dogs of compounds $a, b$ and $d$ is $5-10 \mathrm{mgm} . / \mathrm{kgm}$., as compared with 1-2 mgm. $/ \mathrm{kgm}$. for amidone; but the effect has not been accompanied by the gastro-intestinal disturbances which are common with amidone or morphine. The compounds also exhibit considerable antihistamine, spasmolytic and local anæsthetic activity.

\begin{tabular}{|c|c|c|c|}
\hline $\begin{array}{l}\text { Com- } \\
\text { pound }\end{array}$ & Formula & $\begin{array}{c}\text { Hydro- } \\
\text { chloride } \\
\text { (m.p.) }\end{array}$ & $\begin{array}{c}\text { Analgesic } \\
\text { activity } \\
\text { (P.95 limits) }\end{array}$ \\
\hline $\begin{array}{l}a \\
b \\
c \\
d \\
e\end{array}$ & 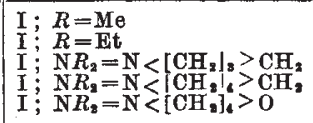 & $\begin{array}{l}169-170^{\circ} \\
152-153 \\
167-169 \\
188-189 \\
181-182\end{array}$ & $\begin{array}{l}1 \cdot 0(0 \cdot 87-1 \cdot 2) \\
1 \cdot 0(0 \cdot 83-1 \cdot 1) \\
0 \cdot 7(0 \cdot 58-0 \cdot 84) \\
1 \cdot 1(0 \cdot 97-1 \cdot 3) \\
0 \cdot 3(0 \cdot 23-0 \cdot 37)\end{array}$ \\
\hline $\begin{array}{c}\text { Morph- } \\
\text { ine }\end{array}$ & - & - & $1 \cdot 0$ \\
\hline
\end{tabular}

A limited analogy may be drawn between this and the amidone series, in so far as compounds of either series which lack the methyl side-chain are considerably less active. On the other hand, the morpholino group, which in the amidone structure (II; $\mathrm{N} R_{2}=$ $\mathrm{N}<\left[\mathrm{CH}_{2}\right]_{4}>\mathrm{O}$ ) promotes the highest activity in the rat ${ }^{1}$, has an unfavourable effect in this series (compound $e$ ); however, this divergence may not be so marked in other animals.

It has recently been stated ${ }^{2}$ that amidone falls into line with other synthetic analgesics in that its spatial atomic arrangement bears a close relationship to that of morphine ; but it is difficult to discern any such structural similarity between the compounds (I) and morphine.

$$
(\overbrace{\mathrm{S}}^{\|})_{2} \mathrm{C}(\mathrm{OH}) \cdot \mathrm{CH}_{2} \cdot \mathrm{CH} R^{1} \cdot \mathrm{N} R_{2}
$$

The amino-butenes (I) were obtained by the dehydration of the corresponding amino-carbinols (III; $R^{1}=\mathrm{Me}$ ), which were prepared by the action of 2-thienyl-lithium on the appropriate ethyl $\beta$. aminobutyrate. The amino-carbinols themselves are potent spasmolytics; for example, the in vitro and in vivo activity of $3-\mathrm{N}$-piperidino-I : 1-(2'-thienyl)propan-1-ol (III; $R^{1}=\mathrm{H} ; \mathrm{NR}_{2}=\mathrm{N}<\left[\mathrm{CH}_{2}\right]_{4}>\mathrm{CH}_{2}$; m.p. 70-72 , hydrochloride, m.p. $198^{\circ}$ (decomp.)) is favourable in relation to synthetic spasmolytics now in clinical use. The amino-carbinols are also potent local anæsthetics.

This work forms part of a programme for the synthesis and pharmacological investigation of amino. alkyl tertiary carbinols and derived products, part of which is already described ${ }^{3}$.

\section{W. Adamson}

A. F. GREeN

Wellcome Research Laboratories,

Beckenham, Kent.

Aug. 30.

${ }^{1}$ Attenburrow, J., Elks, J., Hems, B. A., and Speyer, K. N., J. Chem. Soc., 510 (1949).

${ }^{2}$ Bergel, F., and Morrison, A. L., Quart. Rev., Chem. Soc., 2, 381 (1948),

${ }^{3}$ Adamson, D. W., J. Chem. Soc., S 144 (1949).

\section{Exchange in Cobalt Chelate Compounds}

RECENT advances in nutrition chemistry have indicated the importance of co-ordination compounds in the uptake of cobalt by animals. With the advent of supplies of cobalt-60, obtained through the courtesy of the U.S.A.E.C., we in Adelaide have become interested in the possible exchange reactions between cobaltous ions and cobalt chelate compounds. Flagg ${ }^{1}$, McCallum and Hoshowsky ${ }^{2}$ have reported no evidence for exchanges of this type with a number of cobaltammines. However, Pauling ${ }^{3}$ has pointed out that for co-ordination compounds the bond between the metal and its co-ordinated groups will be predominantly ionic if the compound exhibits a high paramagnetism, for example, 3-5 $\mu$. It therefore appeared to us that exchange by an ionic mechanism should occur between metal ions and those co-ordination compounds of the metal which show high values of $\mu$. Evidence for this theory has been presented by Johnson and Hall in their work on the exchange of nickel derivatives with $\mathrm{Ni}^{++}$ions.

The experimental procedure adopted in our work has been to mix solutions of chelate and cobalt sulphate, equimolal with respect to cobalt, and then to separate the two after various time intervals, by an extraction procedure. The tracer, cobalt-60, is always placed in the cobalt sulphate, and evidence for exchange is based on the appearance of activity in the chelate extract, activities being measured by a solution type, jacketed counter, holding $10 \mathrm{ml}$. Three extraction methods are employed : (1) watersoluble chelates are mixed with aqueous cobalt sulphate and the $\mathrm{Co}^{++}$extracted as the thiocyanate complex with ether; (2) pyridine-soluble chelates are mixed with aqueous cobalt sulphate and the chelate extracted with chloroform; (3) insoluble chelates are shaken with aqueous cobalt sulphate, filtered off, dissolved in hydrochloric acid and counted. The following results are of interest (Table 1).

\begin{tabular}{|c|c|c|c|c|}
\hline Cobalt compound & Extraction & Temp. & $\mu^{s}$ & Remarks \\
\hline Disalicylaldehyde & (2) & $20^{\circ}$ & $4 \cdot 5$ & $\begin{array}{l}\text { Complete ex- } \\
\text { change within }\end{array}$ \\
\hline Guaiacol & (3) & $20^{\circ}$ & $4 \cdot 5$ & $\begin{array}{l}50 \text { sec. } \\
\text { Steady exchange } \\
\text { becoming com- } \\
\text { plete in just over } \\
2 \mathrm{hr} \text {. }\end{array}$ \\
\hline $\begin{array}{l}\text { Trisethylenedi- } \\
\text { amine chloride }\end{array}$ & (1) & $20^{\circ}$ & 0 & $\begin{array}{l}\text { No exchange over } \\
24 \mathrm{hr} \text {. }\end{array}$ \\
\hline Disalicylaldoxime & $\begin{array}{l}(2) \\
(2)\end{array}$ & $\begin{array}{l}20^{\circ} \\
45^{\circ}\end{array}$ & $2 \cdot 6$ & $\begin{array}{l}\text { Slight exchange } \\
\text { (see later) }\end{array}$ \\
\hline
\end{tabular}

Table 1 